\title{
Recessive, Day Length-Insensitive Earliness to Synchronize Flowering of Pearl Millet Hybrid Parents
}

\author{
F. R. Bidinger,* C. T. Hash, R. Jayachandran, and M. N. V. Ratnaji Rao
}

\begin{abstract}
The availability of recessive genes for early flowering-day length insensitivity offers an opportunity to synchronize the flowering of lateflowering or day length-sensitive parents with that of early-flowering parents without necessarily affecting the flowering of their hybrids, provided that the earlier parent does not carry the same recessive allele. This study evaluated the hypothesis that incorporating the recessive $e_{1}$ allele for early flowering-day length insensitivity into a late-flowering, photoperiod-sensitive pollinator in pearl millet [Pennisetum glaucum (L.) R. Br.] would synchronize its flowering and improve seed production with earlier-flowering female parents, without affecting the time to flowering or the performance of the resulting hybrids. An $e_{1} / e_{1}$ isoline of the late-flowering pollinator ICMP 85410, produced by six backcrosses, flowered $16 \mathrm{~d}$ earlier under natural day lengths at Patancheru, India, $\left(17^{\circ} \mathrm{N}\right)$ and $19 \mathrm{~d}$ earlier under extended day lengths (equivalent to $29^{\circ} \mathrm{N}$ ) than its near isogenic $E_{l} / E_{1}$ counterpart. As a consequence, it successfully produced hybrid seed when sown simultaneously with early, male-sterile line $843 \mathrm{~A}$, whereas the late isoline failed under the same conditions. The $E_{l} / e_{1}$ versions of eight near-isogenic hybrids (on a range of eight $E_{l} / E_{1}$ male-steriles) flowered an average of $3 \mathrm{~d}$ earlier than their $E_{1} / E_{1}$ counterparts in 2 yr of tests under both natural and extended day length conditions at the same location. This earlier flowering had small effects on hybrid yield components, consistent with known effects of earliness in the crop, but did not affect grain yield. The results indicate that the $e_{1}$ allele is a powerful tool for exploiting heterosis between early- and late-flowering parents in pearl millet, which is otherwise difficult to realize without complicated seed production practices.
\end{abstract}

$\mathrm{T}$ RADITIONAL CULTIVARS of most tropical cereals depend on strong sensitivity to photoperiod to regulate their time of flowering to match the environment of their origin. Moving such germplasm to other latitudes, even within the tropics, results in its flowering at inappropriate times for the new environments, and increases the probability of drought, disease, pest, bird, or weather damage (Curtis, 1968; Bonhomme et al., 1994; Coffman and Hargrove, 1989). Extensive use of tropical germplasm in breeding programs for subtropical or temperate latitudes usually requires conversion to a less day length-sensitive form that will flower in the desired time in the longer day environments of these latitudes. This can be done either by crossing with adapted, less day length-sensitive material and selecting for early flowering progenies (Abebe Menkir et al., 1994; Hoffbeck et al., 1995) or by a deliberate program of conversion to day length-insensitive forms (Stephens et al., 1967; Duncan et al., 1991).

Burton (1981) and Hanna and Burton (1985) reported

International Crops Research Institute for the Semi-Arid Tropics, ICRISAT Patancheru PO, Andhra Pradesh 502 324, India. ICRISAT Journal Article No. 2247. Received 17 July 1998. *Corresponding author (f.bidinger@cgiar.org).

Published in Crop Sci. 39:1049-1054 (1999). two day length-insensitive early flowering mutants in pearl millet that significantly reduced flowering time under summer day lengths of Georgia. Burton (1981) proposed to use such genes in backcross programs to introduce early flowering and photoperiod insensitivity into otherwise valuable late-flowering, day length-sensitive breeding lines and hybrid parents to extend their area of adaptation, particularly into longer day subtropical or temperate latitude environments. Early, day length-insensitive parental lines bred in this manner in the Tifton, GA, pearl millet program, have been widely used in breeding programs targeting long day length environments of the U.S. central Great Plains (Stegmeier et al., 1987).

For intermediate latitude tropical areas, some degree of day length sensitivity is desirable, as lines homozygous for day length insensitivity characteristically flower too early to be of direct use. However, the $e_{1}$ and $e_{2}$ alleles for photoperiod-insensitive early flowering in pearl millet reported by Burton (1981) and Hanna and Burton (1985) are both recessive, suggesting that they could be present in one parent of a hybrid, without modifying the flowering behavior of the hybrid itself provided the other parent did not carry the same recessive allele. The flowering of the hybrid would thus be largely determined by the (adapted) photoperiod response of the other parent, which carries the dominant allele. Theoretically, this provides the opportunity to use these recessive alleles to advance flowering in otherwise desirable but late-flowering and/or highly day lengthsensitive parental lines. This could improve synchrony of parental line flowering in hybrid seed production plots, reducing the unit cost of seed multiplication, without affecting the day length response of the resulting hybrid. Lack of synchrony of flowering is a severe limitation to the choice of parental combinations that can be used in hybrid pearl millet breeding, often limiting the commercial exploitation of significant heterosis found in testcrosses produced by hand pollination.

This study was carried out to test the hypotheses that (i) the $e_{1}$ gene could be used to improve synchrony of flowering of the parents and the ease of seed production of a high-yielding experimental pearl millet hybrid made from parents whose flowering is not synchronous, and (ii) backcrossing the $e_{1}$ allele into the restorer line would not affect the time to flowering and yield of its hybrids made on $E_{1}$ male-sterile lines.

\section{MATERIALS AND METHODS}

\section{Breeding of ICMR 94410 ( = ICMP $85410 e_{1} / e_{1}$ )}

ICMR 94410 was bred by bulking selfed seed produced on the single earliest-flowering $\mathrm{BC}_{6} \mathrm{~F}_{4}$ progeny out of 197 grown under artificially extended day length conditions at ICRISAT- 
Patancheru during the cool, dry postrainy season of 19921993. The $e_{1}$ donor parent used was LGD-1-B-10 (Hash and Witcombe, 1994), which carries the Katherine source $e_{1}$ allele (Burton, 1981). Elite, late-flowering, photoperiod-sensitive, dwarf inbred pollinator ICMP 85410 (Talukdar et al., 1998) was the recurrent parent. Pollen from early-flowering segregants grown under extended day length conditions (presumed to be $e_{1} / e_{1}$ homozygotes) in the $\mathrm{BC}_{1} \mathrm{~F}_{2}, \mathrm{BC}_{3} \mathrm{~F}_{2}$, and $\mathrm{BC}_{5} \mathrm{~F}_{2}$ generations was used to pollinate the stigmas of recurrent parent ICMP 85410 , to produce heterozygous $E_{1} / e_{1} \mathrm{BC}_{2} \mathrm{~F}_{1}, \mathrm{BC}_{4} \mathrm{~F}_{1}$ and $\mathrm{BC}_{6} \mathrm{~F}_{1}$ versions of the line. In the same manner, pollen from late-flowering $\mathrm{F}_{1}, \mathrm{BC}_{2} \mathrm{~F}_{1}$, and $\mathrm{BC}_{4} \mathrm{~F}_{1}$ plants grown under natural day length conditions (presumed to be $E_{l} / e_{l}$ heterozygotes) was applied to the stigmas of recurrent parent ICMP 85410, to produce $\mathrm{BC}_{1} \mathrm{~F}_{1}, \mathrm{BC}_{3} \mathrm{~F}_{1}$, and $\mathrm{BC}_{5} \mathrm{~F}_{1}$ progenies, each of which segregated 1:1 for $E_{l} / e_{1}$ and $E_{l} / E_{1}$ individuals. Selfing five plants in each of these $\mathrm{BC}_{n} \mathrm{~F}_{1}$ progenies $(n=1,3,5$, or 6$)$ produced seed for $\mathrm{BC}_{n} \mathrm{~F}_{2}$ progeny rows that were then screened under extended day length conditions to identify $e_{1} / e_{1}$ segregants. Early-flowering $\mathrm{BC}_{6} \mathrm{~F}_{3}$ families were selfed and head-rowed under extended day length conditions, and selfed seed from the earliest of the resulting $\mathrm{BC}_{6} \mathrm{~F}_{4}$ progenies from a uniformly early family was bulked to form ICMR 94410 .

\section{Flowering of ICMR $94410\left(e_{1} / e_{1}\right)$ and ICMP $85410\left(E_{l} / E_{1}\right)$}

Responses to photoperiod of inbreds ICMR 94410, ICMP 85410 , and 843B (maintainer line of male-sterile seed parent 843A) were evaluated in a set of separate experiments at Patancheru during the rainy seasons of 1993 and 1994, and the hot, dry "summer" season (the normal season for commercial multiplication of pearl millet hybrid seed in India) of early 1995. In the 1993 experiment, $e_{1}$ allele donor LGD-1-B-10 was also included, but additional plots of $843 \mathrm{~B}$ were substituted in subsequent years of these trials because of extreme susceptibility of the $e_{1}$ donor to pearl millet downy mildew caused by Sclerospora graminicola (Sacc.) J. Schröt. The evaluations consisted of two replications of single-row plots of 2-m length in each of two photoperiod regimes; one the natural day length for Patancheru $\left(17^{\circ} \mathrm{N}\right)$ of 13.9 hours at planting and the other an extended day length treatment (14.7 h at planting) simulating the latitude of the Haryana Agriculture University campus $\left(29^{\circ} \mathrm{N}\right)$ in the northern part of the Indian pearl millet growing zone. The extended day length treatment was achieved with $100-\mathrm{W}$ incandescent bulbs suspended above the crop on a 3 by $5-\mathrm{m}$ grid. The lights were operated by an automatic time clock, during both the predawn and post-sunset hours; clock settings were changed weekly to mimic the normal day length changes at $29^{\circ} \mathrm{N}$ during the growing season.

\section{Seed Production of 843A $\times$ ICMR 94410 and $843 A \times$ ICMP 85410}

Seed of these hybrids was multiplied in paired isolation plots at ICRISAT-Patancheru during the hot, dry "summer" seasons of 1994 and 1995. The paired plots were sown at the same time, but were separated from each other by a physical barrier of sorghum about $100 \mathrm{~m}$ wide, to minimize pollen movement between the paired plots. Plots consisted of 24 ridges (spaced $0.60 \mathrm{~m}$ apart) and were $40 \mathrm{~m}$ long. Plots were oversown mechanically and manually thinned to $15-20 \mathrm{~cm}$ between plants within rows. Basal fertilization rates were 42 $\mathrm{kg} \mathrm{ha}^{-1} \mathrm{~N}$ and $20 \mathrm{~kg} \mathrm{ha}^{-1} \mathrm{P}$, and additional $45 \mathrm{~kg} \mathrm{ha}^{-1} \mathrm{~N}$ was side dressed approximately $20 \mathrm{~d}$ after emergence. The crop was fully irrigated and all weeding, fertilization and cultivation operations were mechanized.

Simultaneous sowings of parental lines were made in a ratio of 4 rows early-flowering, male-sterile seed parent $843 \mathrm{~A}$ to four rows of pollinator $\left(e_{1} / e_{1}\right.$ or $\left.E_{1} / E_{1}\right)$. In the seed production plot with the $E_{1} / E_{1}$ pollinator ICMP 85410 , a second sowing of the seed parent was made on half of the plot 2 wk after seedling emergence of the first sowings, in an attempt to synchronize the flowering of the pollinator and seed parent (this would have to be done in commercial seed production of this hybrid). Seed produced for yield estimation on the A-line rows was harvested from between 4 and 20 (1994) and 3 and 4 (1995) subplots of 1 row $4 \mathrm{~m}$ long in each of the three sowings each year; the actual number of subplots varied with the individual hybrid combination. Paired $t$ tests ( 1 degree of freedom) were used to compare: (i) the mean seed yields for the two seed parent sowing dates for the hybrid produced with pollinator ICMP $85410\left(E_{l} / E_{l}\right)$ and (ii) the mean seed yield of the delayed sowing of the seed parent with pollinator ICMP $85410\left(E_{l} / E_{l}\right)$, with the mean seed yield of the simultaneous sowing of the seed parent and pollinator ICMR 94410 $\left(e_{1} / e_{1}\right)$.

\section{Comparison of ICMR 94410 hybrids $\left(E_{l} / e_{1}\right)$ and ICMP 85410 hybrids $\left(E_{l} / E_{l}\right)$}

To evaluate the effects of having the $e_{1}$ allele in hybrids in a heterozygous form, we crossed near-isogenic ICMR 94410 $\left(e_{1} / e_{1}\right)$ and ICMP $85410\left(E_{l} / E_{l}\right)$ on a set of eight male-sterile lines (none of which, to our knowledge, contains the $e_{1}$ gene, i.e., all are $\left.E_{1} / E_{1}\right)$ to produce a set of eight paired $E_{1} / e_{1}$ and $E_{l} / E_{l}$ hybrids. The male-sterile lines used were 5141A (Pokhriyal et al., 1976), 81A (Anand Kumar et al., 1984), 833A, 843A, 862A, 863A, ICMA 88004 (Rai et al., 1995), and ICMA 89111 (Rai and Rao, 1998). 5141A was bred by the Indian Agricultural Research Institute, New Delhi, 843A was reselected at ICRISAT-Patancheru from a male-sterile line (AKM 79-2068) received from Kansas State University and the remainder are products of the ICRISAT-Patancheru breeding program.

These 16 hybrids were evaluated in two adjacent experiments at ICRISAT-Patancheru during each of the 1993 and 1994 rainy seasons, planted on June 29 each year in an alfisol (Udic Rhodustalf, Patancheru series) field. Each experiment was a different day length treatment-one the natural day length for Patancheru $\left(17^{\circ} \mathrm{N}\right)$ of $13.9 \mathrm{~h}$ at planting and the other an extended day length treatment (14.7 h at planting) simulating the latitude of the Haryana Agriculture University campus $\left(29^{\circ} \mathrm{N}\right)$ in the northern part of the Indian pearl millet growing zone. These two day length treatments were used to test for possible interactions of the genes at the $E_{1} / e_{1}$ locus with day length. The extended day length treatment was managed as described above for the evaluation of time to flowering of ICMR 94410 and ICMP 85410.

All four experiments were sown in a split-plot design, with hybrid (male-sterile line) as the main plot and the $E_{1} / e_{1}$ and $E_{l} / E_{l}$ versions of each hybrid as the sub plots. The experiments were replicated four times in 1993 and three times in 1994. Plots were 4 rows by $0.75 \mathrm{~m}$ by $4 \mathrm{~m}$. They were machine sown on ridges and thinned to a plant spacing of approximately 15 $\mathrm{cm}$ within the row $\left(10\right.$ plants $\left.\mathrm{m}^{-2}\right)$. Basal fertilizer of $28 \mathrm{~kg}$ $\mathrm{ha}^{-1} \mathrm{~N}$ and $13 \mathrm{~kg} \mathrm{ha}^{-1} \mathrm{P}$ was banded into the ridges before sowing and an additional $45 \mathrm{~kg} \mathrm{~N} \mathrm{ha}^{-1}$ was side dressed at $20 \mathrm{~d}$ after sowing. Weeds were controlled by a combination of interrow cultivation and hand weeding. There was no economically significant incidence of insect, disease, or bird damage to the plots.

Days to flowering was recorded when stigmas were visible on the main stem panicles of $50 \%$ of the plants in the plot. At maturity, a plot sample of $0.75 \mathrm{~m}$ of the center two rows $\left(1.125 \mathrm{~m}^{2}\right)$ was harvested at ground level; plants were counted 
and main shoot and tillers separated, and panicles removed and counted. The fresh weights of the main and tiller stover were recorded, subsamples taken, chopped, and weighed. Main shoot and tiller panicle and stover subsample dry mass were recorded after oven drying at $70^{\circ} \mathrm{C}$ for $3 \mathrm{~d}$. Stover weight was calculated from the total fresh weight and the subsample moisture percentage. The main and tiller panicles were oven dried, weighed, threshed and grain weight recorded. Triplicate estimates of 100 grain mass for both main shoot and tiller grain were used to calculate individual grain mass $(\mathrm{mg})$ and grain number per panicle and per $\mathrm{m}^{2}$ for both main shoot and tiller panicles. Other yield components and harvest index (HI) were calculated from the $1.125-\mathrm{m}^{2}$ samples.

The panicles from the remaining bordered area of the plots $\left(2.25 \mathrm{~m}\right.$ of the center rows $\left.=3.375 \mathrm{~m}^{2}\right)$ were harvested, counted, oven dried, weighed, threshed, and the grain weighed. Panicle numbers, grain yield, and biomass (grain yield divided by $\mathrm{HI}$, as estimated from the subsample) were calculated from the combination of the large and small harvested areas $\left(4.5 \mathrm{~m}^{2}\right)$. Growth rate $\left(\mathrm{g} \mathrm{m}^{-2} \mathrm{~d}^{-1}\right)$ was estimated as the quotient of biomass and days to flowering plus $25 \mathrm{~d}$.

The trials were analyzed as a multi-environment, split plot experiment, with environment ( $3 \mathrm{df}$-divided into the effects of year and day length) tested against the replication-withinenvironment MS (10 df). Hybrid and hybrid $\times$ environment effects were tested against the hybrid $\times$ replication-withinenvironment MS (70 df), and the effects of the form of $E_{l} / e_{1}$ allele and its interaction with hybrid, environment and hybrid $\times$ environment were tested against the pooled allele $\times$ replication-within-environment and allele $\times$ hybrid $\times$ replicationwithin-environment MS (80 df). Data analysis was done with the GLM procedure of SAS (SAS Institute, 1989).

\section{RESULTS AND DISCUSSION}

\section{Effects of Incorporating the $e_{1}$ Allele Into the Genetic Background of ICMP 85410}

\section{Time to Flowering}

Transfer of early flowering from the donor LGD-1B-10 to the genetic background of ICMP 85410 was successful. ICMR 94410 was significantly earlier to flower (by an average of $17.5 \mathrm{~d}$ ) than its recurrent parent, ICMP 85410 , across six photoperiod $\times$ sowing date combinations (Table 1). In addition, ICMR 94410 was less affected by the extended photoperiods (average of 3 d delay in flowering under the long photoperiods, compared with the short photoperiods) than its recur- rent parent (average of $6 \mathrm{~d}$ delay). This difference in photoperiod response was especially clear in the February planting in which the natural day length is only $12.3 \mathrm{~h}$, compared with13.9 $\mathrm{h}$ in June, where flowering was delayed by a full $10 \mathrm{~d}$ in ICMP 85410 under the extended day length, compared with a delay of only $3 \mathrm{~d}$ in ICMR 94410 (Table 1). ICMR 94410 was nearly as early and as insensitive to photoperiod as its donor parent in 1993 (the only season in which this comparison was made) and was always at least as early to flower as 843B. Tillering of ICMR 94410 was substantially greater and less synchronous than that of ICMP 85410 (data not shown). Both of these observations suggest that economical seed multiplication of the hybrid 843A $\times$ ICMR 94410 should be possible with simultaneous sowings of the parental lines-regardless of day lengthunlike the case of the originally identified hybrid combination $843 \mathrm{~A} \times \mathrm{ICMP} 85410$.

\section{Hybrid Seed Production}

As expected from the parental line flowering data reported above, the flowering of the parental lines in the seed multiplication plots were perfectly synchronized in the case of the hybrid 843A $\times$ ICMR 94410 (Fig. 1a), in contrast to the flowering of the parents in the case of hybrid 843A $\times$ ICMP 85410 (Fig. 1b). Seed yields from simultaneous sowings of 843A and ICMR 94410 were nearly three-fold greater than those from the staggered sowings of 843A and ICMP 85410 (Table 2). The simultaneous sowing of the latter two lines resulted in complete failure of seed multiplication because of the lack of pollen at the time of flowering of the seed parent.

\section{Comparison of ICMR 94410 Hybrids $\left(E_{l} / e_{1}\right)$ and ICMP 85410 Hybrids $\left(E_{l} / E_{l}\right)$}

\section{Crop Growth and Yield}

Year and day length had significant effects on time to flowering, growth rate, and productivity of the eight pairs of near-isogenic hybrids (Table 3). Flowering was $4 \mathrm{~d}$ later, and biomass, growth rate and grain yield were 45 to $50 \%$ greater in 1993 than in 1994 (Table 4). However, harvest index did not differ between years. The mean trial grain yield and biomass achieved in 1993 ,

Table 1. Time to flowering of pearl millet inbred pollinators ICMP 85410, ICMR 94410, seed parent maintainer 843B, and $e_{1}$ allele donor LGD-1-B-10, in natural (13.9 h) and extended (14.7 h) daylengths across three sowing dates at Patancheru, India, $1993-1995$. Total number of observations across sowing dates for each genotype $\times$ daylength combination is indicated in parentheses.

\begin{tabular}{|c|c|c|c|c|c|c|c|c|}
\hline \multirow[b]{3}{*}{ Genotype } & \multicolumn{8}{|c|}{ Time to $50 \%$ flowering (days) for three sowing dates } \\
\hline & \multicolumn{2}{|c|}{29 Jun 1993} & \multicolumn{2}{|c|}{20 Jun 1994} & \multicolumn{2}{|c|}{02 Feb 1995} & \multicolumn{2}{|c|}{ Mean } \\
\hline & Extended & Natural & Extended & Natural & Extended & Natural $\dagger$ & Extended & Natural \\
\hline $\begin{array}{c}\text { ICMP } 85410 \\
\left(E_{l} / E_{l}\right)\end{array}$ & 57.5 & 52.5 & 59.5 & 56.1 & 59.5 & 49.5 & $\begin{array}{l}58.3 \\
(6)\end{array}$ & $\begin{array}{l}52.3 \\
(6)\end{array}$ \\
\hline $\begin{array}{c}\text { ICMR } 94410 \\
\left(e_{1} / e_{1}\right)\end{array}$ & 39.5 & 38.0 & 41.5 & 37.0 & 37.0 & 34.0 & $\begin{array}{l}39.3 \\
\text { (6) }\end{array}$ & $\begin{array}{l}36.3 \\
\text { (6) }\end{array}$ \\
\hline $\begin{array}{l}843 \mathrm{~B} \\
\quad\left(E_{l} / E_{I}\right)\end{array}$ & 46.5 & 38.0 & 45.0 & 38.3 & 48.0 & 35.8 & $\begin{array}{l}46.4 \\
(10)\end{array}$ & $\begin{array}{l}37.2 \\
\text { (10) }\end{array}$ \\
\hline $\begin{array}{c}\text { LGD-1-B-10 } \\
\left(e_{1} / e_{1}\right)\end{array}$ & 37.0 & 36.5 & -+ & - & - & - & $\begin{array}{l}37.0 \\
(2)\end{array}$ & $\begin{array}{l}36.5 \\
\text { (2) }\end{array}$ \\
\hline SE & & $\pm \mathbf{0 . 9}$ & & \pm 0.5 & & $\pm \mathbf{0 . 3}$ & & \\
\hline
\end{tabular}

$\dagger$ Natural daylength in February is approximately $12.3 \mathrm{~h}$, in contrast to $13.9 \mathrm{~h}$ in June-July.

\$ No data. 

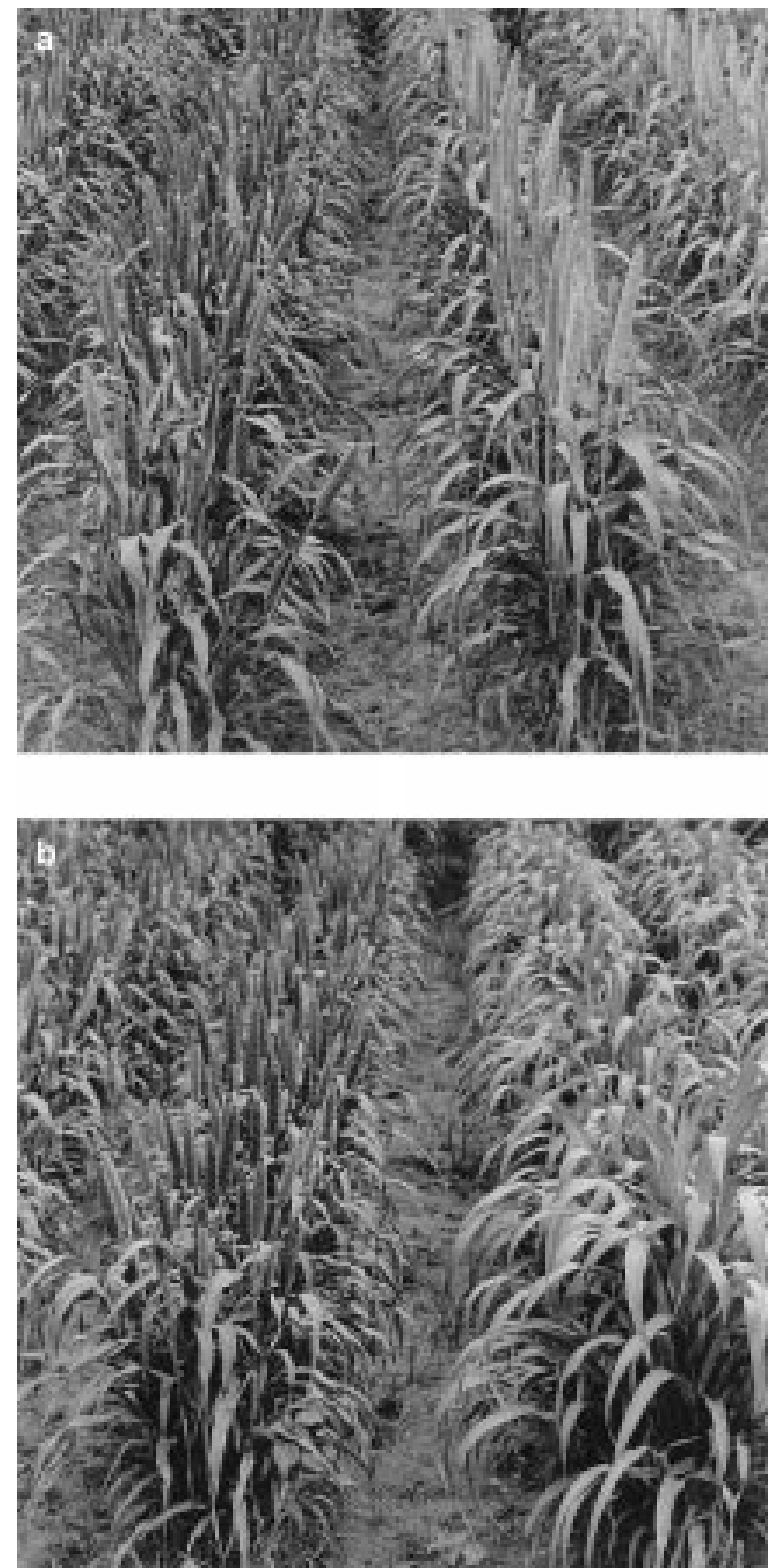

Fig. 1. (a) Pollinator ICMR 94410 ( $e_{1} / e_{1}$ version of ICMP 85410), on the right, and seed parent $843 \mathrm{~A}$, on the left, when sown at the same time in a hybrid seed production plot. The synchronized flowering of the two parents assures reliable hybrid seed production. (b) The original ( $E_{1} / E_{1}$ version) of pollinator ICMP 85410, on the right and seed parent $843 \mathrm{~A}$, on the left, when sown at the same time in a hybrid seed production plot. The lack of synchrony in flowering of the two parents necessitates staggered sowing of the two parents to achieve hybrid seed production.

particularly under the extended day length $\left(5.2 \mathrm{Mg} \mathrm{ha}^{-1}\right.$ grain and $14.1 \mathrm{Mg} \mathrm{ha}^{-1}$ biomass) were very high for the location. The longer day length of $14.7 \mathrm{~h}$ delayed flowering by $5.5 \mathrm{~d}$, and increased growth rate by $13 \%$ (Table 4). The combined effects of increased growth duration and increased growth rate increased total biomass by $22 \%$ and grain yield by $14 \%$ under the extended day length treatments. However, harvest index was slightly reduced $(2.3 \%, P<0.08)$ by the longer days (Table 3). The interaction of year and day length effects were significant for harvest index $(P<0.04)$ and mar-
Table 2. Seed yields of 843A $\times$ ICMR $94410\left(e_{1} / e_{1}\right)$ and 843A $\times$ ICMP $85410\left(E_{l} / E_{l}\right)$, with both simultaneous and delayed sowings of the seed parent, in experimental seed production plots of Patancheru, India, 1994 and 1995. The number of within-plot observations for each year $\times$ treatment combination is indicated in parentheses.

\begin{tabular}{cccc}
\hline & \multicolumn{3}{c}{ Seed yield $\pm \mathrm{SD}\left(\mathrm{g} \mathrm{m}^{-2}\right)$} \\
\cline { 2 - 4 } & 1994 & 1995 & Mean \\
\hline $\begin{array}{c}\text { Simultaneous sowings of seed and } \\
\text { pollen parents }\end{array}$ & & & \\
$843 \mathrm{~A} \times$ ICMR 94410 & $304 \pm 97$ & $304 \pm 72$ & $304 \pm 0.3$ \\
$843 \mathrm{~A} \times$ ICMP 85410 & $(4)$ & $(3)$ & $9 \pm 0.5$ \\
$\begin{array}{c}\text { Delayed sowing of seed parent } \\
\text { 843A } \times \text { ICMP 85410 }\end{array}$ & $\mathbf{( 4 )}$ & $\mathbf{9} \pm 11$ & $(3)$ \\
& $\mathbf{1 1 3} \pm 35$ & $\mathbf{9 3} \pm 23$ & $103 \pm 14.1$ \\
\hline
\end{tabular}

ginal for flowering $(P<0.06)$, but not significant for growth rate, biomass or grain yield.

Hybrids (hybrid pairs) differed from each other, as expected, and also differed in their response to the growing conditions in the two years and to the natural and extended day length environments, for all variables except harvest index (hybrid $\times$ year and hybrid $\times$ day length interactions, Table 3). The three highest yielding hybrid pairs, were those on 862A, 863A, and ICMA 88004 (Table 4). The first of these was late flowering with an average growth rate and harvest index, resulting in a high biomass productivity and a consequently a high grain yield. The second and third were early flowering, with high growth rates and higher than average harvest indices (Table 4). These three hybrid pairs were, in general, also responsible for the significant hybrid $x$ year and hybrid $\times$ day length interactions, as they were more responsive to the more favorable environment of 1993 and to the extended day length treatment. For example, the hybrids on late seed parent $862 \mathrm{~A}$, which were the most responsive to better conditions, delayed flowering by $7 \mathrm{~d}$ and increased growth rate from $14.3 \mathrm{~g}$ $\mathrm{m}^{-2} \mathrm{~d}^{-1}$ to $17.6 \mathrm{~g} \mathrm{~m}^{-2} \mathrm{~d}^{-1}$ in the extended day length, with a consequent production of an additional $356 \mathrm{~g}$ $\mathrm{m}^{-2}$ biomass and $139 \mathrm{~g} \mathrm{~m}^{-2}$ of grain mass. In comparison, hybrids based on early seed parent 843A flowered $6 \mathrm{~d}$ later under extended day length, but increased growth rates from only $12.1 \mathrm{~g} \mathrm{~m}^{-2} \mathrm{~d}^{-1}$ to $13.8 \mathrm{~g} \mathrm{~m}^{-2} \mathrm{~d}^{-1}$, adding only $185 \mathrm{~g} \mathrm{~m}^{-2}$ biomass and $38 \mathrm{~g} \mathrm{~m}^{-2}$ grain mass (data not presented).

Backcrossing of the $e_{1}$ allele into ICMP 85410 significantly affected the time to flowering $(P<0.001)$ and harvest index $(P<0.016)$ and slightly affected the biomass $(P=0.07)$ of its hybrids, but not their growth rate or grain yield (Table 3 ). The absolute effects on the hybrids of introducing the $e_{1}$ allele into the pollinator were not large, however, despite their statistical significance: a 3-d advance in flowering, a 3\% decrease in biomass, and a $1 \%$ increase in harvest index (Table 4). The effects of the $e_{1}$ allele on biomass and on harvest index were almost certainly a consequence of it effects on time to flowering, as growth rate did not change. The shorter vegetative period in the $E_{l} / e_{1}$ versions of hybrids resulted in less total vegetative growth and a consequent higher harvest index, as grain yields were 
Table 3. Probability of significance of effects and interactions from the combined analysis of variance for time to flowering, biomass, growth rate [biomass/(time to flower $+25 \mathrm{~d})$ ], harvest index and grain yield of eight ICMR 94410 hybrids $\left(E_{l} / e_{1}\right)$ and their ICMP 85410 counterparts $\left(E_{l} / E_{l}\right)$. Data are from trials at Patancheru, India, 1993 and 1994, conducted under natural (13.9 h) and extended (14.7 h) daylengths.

\begin{tabular}{|c|c|c|c|c|c|c|}
\hline $\begin{array}{l}\text { Source of } \\
\text { variation }\end{array}$ & df & $\begin{array}{c}\text { Days to } \\
\text { flower }\end{array}$ & Biomass & $\begin{array}{c}\text { Growth } \\
\text { rate }\end{array}$ & $\begin{array}{c}\text { Harvest } \\
\text { index }\end{array}$ & $\begin{array}{c}\text { Grain } \\
\text { yield }\end{array}$ \\
\hline Year (Yr) & 1 & 0.001 & 0.001 & 0.001 & $\mathbf{N S} \dagger$ & 0.001 \\
\hline Daylength (DI) & 1 & 0.001 & 0.001 & 0.001 & 0.072 & 0.001 \\
\hline $\mathbf{Y r} \times \mathbf{D l}$ & 1 & 0.064 & NS & NS & 0.043 & NS \\
\hline Hybrid (Hyb) & 7 & 0.001 & 0.001 & 0.001 & 0.001 & 0.001 \\
\hline Hyb $\times$ Yr & 7 & 0.001 & 0.001 & 0.014 & NS & 0.001 \\
\hline Hyb $\times$ DI & 7 & 0.052 & 0.020 & 0.041 & NS & 0.023 \\
\hline Hyb $\times$ Yr $\times$ Dl & 7 & NS & NS & NS & NS & NS \\
\hline Allele (AI) & 1 & 0.001 & 0.070 & NS & 0.016 & NS \\
\hline $\mathbf{A l} \times \mathbf{Y r}$ & 1 & NS & NS & NS & NS & NS \\
\hline $\mathbf{A l} \times \mathbf{D I}$ & 1 & NS & NS & NS & NS & NS \\
\hline $\mathbf{A l} \times \mathbf{Y r} \times \mathbf{D l}$ & 1 & NS & NS & NS & NS & NS \\
\hline $\mathbf{A l} \times \mathbf{H y b}$ & 7 & NS & NS & NS & NS & NS \\
\hline Al $\times$ Hyb $\times \mathbf{D l}$ & 7 & NS & NS & NS & NS & NS \\
\hline $\mathbf{A I} \times \mathbf{H y b} \times \mathbf{Y r}$ & 7 & 0.001 & NS & NS & 0.037 & NS \\
\hline \multicolumn{7}{|l|}{$\mathbf{A I} \times \mathbf{H y b} \times \mathbf{Y r}$} \\
\hline$\times \mathbf{D i}$ & 7 & 0.073 & 0.090 & 0.059 & NS & 0.083 \\
\hline Subplot CV (\%) & & 2.8 & 12.9 & 13.1 & 9.3 & 11.6 \\
\hline
\end{tabular}

$\dagger \mathbf{N S}=P>\mathbf{0 . 1 0}$.

unchanged from those of their $E_{1} / E_{1}$ counterparts. There was no evidence of interaction of the $e_{1}$ allele with environment-year and day length-or with hybrid (i.e., male-sterile line), for any of the variables measured (Table 3). The only significant interactions involving the $e_{1}$ gene were allele $\times$ hybrid $\times$ year for flowering and harvest index, and the four way interaction for all variables but harvest index .

Thus the data from this experiment do not support the hypothesis that backcrossing the recessive $e_{1}$ allele into the pollinator does not affect the flowering of the hybrid. There are several possible explanations for this involving either the action of the allele itself, possible linkage to a non-photoperiod-related maturity gene(s), or the procedure used to backcross it into ICMP 85410. For example, the selection of the earliest-flowering lines in the $\mathrm{BC}_{n} \mathrm{~F}_{2}$ generations for the backcross transfer of the $e_{1}$ allele, may also have resulted in the transfer of alleles at other loci contributing to the early flowering of donor parent LGD-1-B-10. However, despite the statistical significance of several of these differences between $E_{1} / e_{1}$ and $E_{1} / E_{1}$ hybrid pairs, they are generally sufficiently small to be of little, if any, practical importance to pearl millet grain producers.

\section{Yield Components}

The more detailed comparison of the two versions of these eight hybrids (Table 5) indicated differences in several yield components that were consistent with known effects of differences in time to flowering in pearl millet (e.g., Craufurd and Bidinger, 1988a). The earlier flowering $E_{1} / e_{1}$ hybrids had more, but less productive, panicles per unit area. The differences were not large agronomically, consistent with the small differences in time to flowering, but were statistically significant. As these were offsetting differences, they produced no dif-
Table 4. Means of the main effects of year, daylength, male-sterile line and allele at the $E_{1} / e_{1}$ locus, on biomass, growth rate, harvest index and grain yield from eight ICMR 94410 hybrids $\left(E_{1} / e_{1}\right)$ and their ICMP 85410 counterparts $\left(E_{1} / E_{1}\right)$. Data are from trials at Patancheru, India, 1993 and 1994, conducted under normal (13.9 h) and extended (14.7 h) daylength.

\begin{tabular}{|c|c|c|c|c|c|}
\hline Effect & Flowering & Biomass & $\begin{array}{l}\text { Growth } \\
\text { rate }\end{array}$ & $\begin{array}{c}\text { Harvest } \\
\text { index }\end{array}$ & $\begin{array}{l}\text { Grain } \\
\text { yield }\end{array}$ \\
\hline & d & $\mathrm{g} \mathrm{m}^{-2}$ & $\mathrm{~g} \mathrm{~m}^{-2} \mathrm{~d}^{-1}$ & $\%$ & $\mathrm{~g} \mathrm{~m}^{-2}$ \\
\hline \multicolumn{6}{|l|}{ Year } \\
\hline 1993 & 47.4 & 1275 & 17.6 & 39.3 & 493 \\
\hline 1994 & 43.3 & 841 & 12.2 & 39.1 & 325 \\
\hline \multicolumn{6}{|l|}{ Daylength } \\
\hline 13.9 hours & 42.9 & 982 & 14.4 & 40.4 & 395 \\
\hline 14.7 hours & 48.4 & 1195 & 16.2 & 38.1 & 449 \\
\hline \multicolumn{6}{|l|}{ Male-sterile line } \\
\hline $5141 A$ & 51.4 & 1205 & 15.8 & 34.0 & 406 \\
\hline $81 \mathrm{~A}$ & 46.0 & 985 & 13.8 & 40.6 & 397 \\
\hline 833A & 44.1 & 967 & 13.8 & 37.7 & 361 \\
\hline $843 A$ & 40.3 & 854 & 13.0 & 43.0 & 368 \\
\hline $862 A$ & $\mathbf{5 0 . 7}$ & 1205 & 15.9 & 38.1 & 460 \\
\hline $863 \mathrm{~A}$ & 44.5 & 1193 & 17.0 & 39.8 & 472 \\
\hline ICMA 88004 & 42.7 & 1187 & 17.3 & 41.1 & 487 \\
\hline ICMA 89111 & 45.4 & 1122 & 15.8 & 39.6 & 431 \\
\hline $\mathbf{S E} \pm$ & 0.2 & 27 & 0.4 & 0.7 & 9 \\
\hline \multicolumn{6}{|l|}{ Allele } \\
\hline$E_{1} / E_{1}$ & 47.0 & 1104 & 15.2 & 38.6 & 422 \\
\hline$E_{1} / e_{1}$ & 44.3 & 1076 & 15.4 & 39.9 & 421 \\
\hline
\end{tabular}

ferences in grain yield between the $E_{1} / e_{1}$ and $E_{1} / E_{1}$ hybrids. The slightly shorter growth duration of the $E_{1} / e_{1}$ hybrids also resulted in a slightly reduced vegetative mass production (measured as stover at harvest), which was the cause of the lower total biomass productivity in these hybrids (Table 5). There were no differences in panicle biomass between the two types of hybrids, however, resulting in the slight increase in harvest index in the $E_{1} / e_{1}$ hybrids (Table 4 ).

These effects of time to flowering on yield components, but not on grain yield, are well documented in pearl millet in studies in which day length treatments were used to modify time to flowering in single hybrids (Carberry and Campbell, 1985; Craufurd and Bidinger, 1988a, b). In the studies of Craufurd and Bidinger (1988a), for example, a 10-d increase in time to flowering in two hybrids in extended compared with natural day lengths, increased total biomass by $50 \%$, but did not affect grain yields. Delayed flowering in their study also reduced panicle number and increased grain mass per panicle by approximately $13 \%$. Genetic differences in

Table 5. Mean yield component and dry matter distribution data of eight ICMR 94410 hybrids $\left(E_{1} / e_{1}\right)$ and their ICMP 85410 counterparts $\left(E_{1} / E_{1}\right)$. Data are means from four environments at Patancheru, India: 1993 and 1994, in natural (13.9 hr) and extended $(14.7 \mathrm{hr})$ daylengths.

\begin{tabular}{|c|c|c|c|}
\hline Yield component & $\begin{array}{c}E_{1} / E_{1} \\
\text { hybrids }\end{array}$ & $\begin{array}{c}E_{1} / e_{1} \\
\text { hybrids }\end{array}$ & $\begin{array}{c}\text { Probability of } \\
\text { difference }\end{array}$ \\
\hline $\begin{array}{l}\text { Panicle number } \mathbf{m}^{-2} \\
\text { Grain number panicle } \\
\text { Grain number }\left(\times \mathbf{1 0}^{-3}\right) \mathbf{m}^{-2} \dagger\end{array}$ & $\begin{array}{c}23.1 \\
1869 \\
41.6\end{array}$ & $\begin{array}{l}25.4 \\
1698 \\
41.7\end{array}$ & $\begin{array}{r}0.001 \\
0.001 \\
\text { NS } \ddagger\end{array}$ \\
\hline $\begin{array}{l}\text { Single grain mass }(\mathrm{mg}) \\
\text { Grain mass panicle } \\
\text { Grain yield }\left(\mathrm{g} \mathrm{m}^{-1}\right)\end{array}$ & $\begin{array}{c}1.03 \\
19.1\end{array}$ & $\begin{array}{c}1.02 \\
17.4\end{array}$ & $\begin{array}{l}\text { NS } \\
0.001 \\
\text { NS }\end{array}$ \\
\hline $\begin{array}{l}\text { Stover mass }\left(\mathrm{g} \mathrm{m}^{-2}\right) \\
\text { Panicle mass }\left(\mathrm{g} \mathrm{m}^{-2}\right) \\
\text { Biomass }\left(\mathrm{g} \mathrm{m}^{-2}\right)\end{array}$ & $\begin{array}{r}525 \\
584 \\
1104\end{array}$ & $\begin{array}{r}\mathbf{5 0 1} \\
\mathbf{5 7 8} \\
\mathbf{1 0 7 6}\end{array}$ & $\begin{array}{r}0.10 \\
\text { NS } \\
0.07\end{array}$ \\
\hline
\end{tabular}

+1000 grains $\mathbf{m}^{-2}$

$+\mathbf{N S}=P>0.10$ 
time to flowering in this study, even of the order of $3 \mathrm{~d}$, had similar consequences on biomass and yield component distribution, but as in the earlier study, no effects on grain yield. Therefore, the small promotive effects on flowering of the $e_{1}$ allele, even in heterozygous form, will probably have no important consequences for grain yield in hybrids in which synchronization of flowering is achieved by backcrossing it into one parent. Small reductions in biomass production in such hybrids, however, could be important in areas in which the dry stover of pearl millet is used as fodder. Increases in panicle numbers to be harvested per unit grain yield from such hybrids might marginally increase grain production costs in regions where manual panicle harvest is prevalent.

\section{Utility of the $e_{1}$ Allele for Hybrid Breeding}

The effects of the $e_{1}$ Katherine allele at the $E_{1} / e_{1}$ locus in pearl millet were statistically significant and substantial when the allele was present in homozygous form, and statistically significant, but of only minor practical importance, when in heterozygous form. The allele conferred substantially earlier flowering and reduced photoperiod sensitivity as previously reported (Burton, 1981; Hanna and Burton, 1985). The suggestion (Burton, 1981) to use such flowering mutants to improve synchrony of flowering of hybrid parental lines, was supported by this work, as effects of this allele in heterozygous form were not large enough to be of much practical importance to hybrid performance. This allele thus provides a mechanism to facilitate exploitation of heterosis between early-flowering seed parents and laterflowering pollinators, increasing the range of parents that can be considered in breeding short- and mediumduration pearl millet hybrids for which seed production is practical. Also the magnitude of effects of the heterozygous $e_{1}$ allele on time to flowering and day length sensitivity suggest that it should be possible to directly backcross this allele into later-flowering and/or photoperiod-sensitive inbreds or populations without the need to pass through a selfing generation after every second cross to the recurrent parent, reducing the time and expense required.

With the development of ICMR 94410, the Katherine source $e_{1}$ allele is now available in an agronomically elite, $d_{2}$ dwarf, pollinator background, which is capable of restoring fertility in both the $\mathrm{A}_{1}$ and $\mathrm{A}_{4}$ cytoplasmicgenic male-sterility systems (C.T. Hash, 1994, unpublished data) and which has much higher levels of resistance to pearl millet downy mildew and better combining ability for grain yield than any previously available background (C.T. Hash, 1997, unpublished data). This line can now be used as an $e_{1}$ allele donor to diversify the range of early-flowering hybrid parents and thereby broaden the genetic base of short- and medium-duration hybrid cultivars.

\section{ACKNOWLEDGMENTS}

The authors thank the many ICRISAT scientists and support staff-past and present-who helped in developing
ICMR 94410, and in producing the seed for and collecting the data from the experiments reported here. For their involvement in the development of ICMR 94410, we specifically acknowledge the contributions of Dr. J.R. Witcombe, Dr. E. Weltzien R., Mr. C. Rama Krishna, Mr. B.P. Reddy, Mr. P. Om Prakash, and Mr. A. Ganapathi

\section{REFERENCES}

Abebe Menkir, P.J. Bramel-Cox, and M.D. Witt. 1994. Selection for agronomically acceptable inbred lines in adapted $\times$ exotic sorghum backcross populations. Crop Sci. 34:1084-1089.

Anand Kumar, D.J. Andrews, R.P. Jain, and S.D. Singh. 1984. ICMA-1 (sic) and ICMB-1 (sic) pearl millet parental lines with A1 cytoplasmic-genic male sterility system. Crop Sci. 24:832.

Bonhomme, R., M. Derieux, and G.O. Edmeades. 1994. Flowering of diverse maize cultivars in relation to temperature and photoperiod in multilocational field trials. Crop Sci. 34:156-164.

Burton, G.W.1981. A gene for early maturity and photoperiod insensitivity in pearl millet. Crop Sci. 21:317-318.

Carberry, P.S., and L.C. Campbell. 1985. The growth and development of pearl millet as affected by photoperiod. Field Crops Res. 11: 207-217.

Coffman, W.R., and T.R. Hargrove. 1989. Modern rice varieties as a possible factor in production variability. p. 133-146. In J.R. Anderson and P.B.R. Hazell (ed.) Variablility in grain yields. Johns Hopkins Univ. Press, Baltimore, MD.

Craufurd, P.Q., and F.R. Bidinger. 1988a. Effect of the duration of the vegetative phase on crop growth, development and yield in two contrasting pearl millet hybrids. J. Agric. Sci. (Cambridge) 110:71-79.

Craufurd, P.Q., and F.R. Bidinger. 1988b. Effect of the duration of the vegetative phase on shoot growth, development and yield in pearl millet (Pennisetum americanum (L.) Leeke). J. Exp. Bot. 39: 124-139.

Curtis, D.L. 1968. The relation between yield and date of heading in Nigerian sorghums. Exp. Agric. 4:93-101.

Duncan, R.R., P.J. Bramel-Cox, and F.R. Miller. 1991. Contributions of introduced sorghum germplasm to hybrid development in the USA. p. 69-101. In Use of plant introductions in cultivar development, Part 1. CSSA Spec. Pub. 17. CSSA, Madison, WI.

Hanna, W.W., and G.W. Burton. 1985. Morphological characteristics and genetics of two mutations for early maturity in pearl millet. Crop Sci. 25:79-81.

Hash, C.T., and J.R. Witcombe. 1994. Pearl millet mapping populations at ICRISAT. p. 69-75. In J.R. Witcombe and R.R. Duncan (ed.) Use of molecular markers in sorghum and pearl millet breeding in developing countries. Overseas Development Administration, London.

Hoffbeck, M.D., S.J. Openshaw, J.L. Geadelmann, R.H. Peterson, and D.D. Stuthman. 1995. Backcrossing and intermating in an exotic $\times$ adapted cross of maize. Crop Sci. 35:1359-1364.

Pokhriyal, S.C., K.V. Unnikrishnana, B. Singh, Ram Dass, and R.R. Patil. 1976. Combining ability of downy mildew resistant lines in pearl millet. Ind. J. Genet. 36:403-409.

Rai, K.N., A.S. Rao, and C.T. Hash. 1995. Registration of pearl millet parental lines ICMA 88004 and ICMB 88004. Crop Sci. 35:1242.

Rai, K.N., and A.S. Rao. 1998. Registration of pearl millet parental lines ICMA 89111 and ICMB 89111. Crop Sci. 38:1412-1413.

SAS Institute. 1989 SAS Users Guide. Statistics Version 5. SAS Institute, Cary, NC

Stegmeier, W.D., B. Khaleeq, and T.L. Harvey. 1987. The potential of pearl millet as a grain crop in the central Great Plains of the USA. p. 316-317. In J.R. Witcombe and S.R. Beckerman (ed.) Proceedings of the international pearl millet workshop, ICRISAT Center, India. 7-11 April 1986. International Crops Research Institute for the Semi-Arid Tropics, Patancheru, A.P., India.

Stephens, J.C., F.R. Miller, and D.T. Rosenow. 1967. Conversion of alien sorghums to early combine genotypes. Crop Sci. 7:396.

Talukdar, B.S., P.P. Prakash Babu, A.M. Rao, C. Ramakrishna, J.R. Witcombe, S.B. King, and C.T. Hash. 1998. Registration of ICMP 85410: Dwarf, downy mildew resistant, restorer parental line of pearl millet. Crop Sci. 38:904-905. 